\title{
Supplement
}

Material and Methods

\section{Media preparation}

5 Sterile-filtered $(0.2 \mu \mathrm{m})$ North Sea seawater (NSW) containing $7.2 \mu \mathrm{mol} \mathrm{L}^{-1}$ silicate was enriched with vitamins and trace metals according to f/2 media (Guillard and Ryther, 1962) as well as with nitrate and phosphate. Final values of nitrate and phosphate were $111.5 \mu \mathrm{mol} \mathrm{L} \mathrm{L}^{-1}$ and $5.85 \mu \mathrm{mol} \mathrm{L}{ }^{-1}$ respectively. Nutrients were measured colourimetrically using a continuous flow analyzer (Evolution III, Alliance Instruments, Salzburg, Austria). The salinity was $32.380 \pm 0.003$ (measured with a Guildline Autosal 8400B, Ontario, Canada). Inorganic artificial seawater (ASW) was prepared from milliQ water and salts as described by Grasshoff et al. (1999), set to a salinity of 35 .

\section{2. $C_{\mathrm{T}}$ Adjustments at constant $\boldsymbol{A}_{\mathrm{T}}$}

$C_{\mathrm{T}}$ adjustments were conducted at $15 \pm 0.2^{\circ} \mathrm{C}$ in $2 \mathrm{~L}$ borosilicate DURAN bottles equipped with glass frits for aeration. The media were sparged continuously with humidified, $0.2 \mu \mathrm{m}$ filtered air of different partial pressures of $\mathrm{CO}_{2}$ (180 and $1000 \mu \mathrm{atm}$, each in triplicates). Gas flow rates were $130 \pm 10 \mathrm{~mL} \mathrm{~min}^{-1}$. Gas mixtures were generated using a custom-made gas flow controller. $\mathrm{CO}_{2}$-free air ( $<1 \mathrm{ppm} \mathrm{CO}_{2}$; Dominick Hunter, Willich, Germany) was mixed with pure $\mathrm{CO}_{2}$ (Air Liquide Deutschland, Düsseldorf, Germany) by a mass flow controller based system (CGM $2000 \mathrm{MCZ}$ Umwelttechnik, Bad Nauheim, Germany). The $\mathrm{CO}_{2}$ concentration was regularly controlled with a non-dispersive infrared analyzer system (LI6252, LI-COR Biosciences, Bad Homburg, Germany) calibrated with $\mathrm{CO}_{2}$-free air and purchased gas mixtures of $150 \pm 10$ and $1000 \pm 20$ ppm $\mathrm{CO}_{2}$ (Air Liquide Deutschland, Düsseldorf, Germany). Seawater samples were taken after 48 hours to ensure equilibration (auxiliary material, Fig. 2).

\section{Alkalinity adjustments at constant $C_{\mathrm{T}}$}

Carbonate chemistry was adjusted by addition of calculated amounts of $\mathrm{HCl}$ or $\mathrm{NaOH}(1 \mathrm{~N}$ Titrisol, Merck, Darmstadt, Germany) to seawater of known $C_{\mathrm{T}}$. The manipulated media were stored in 2 L borosilicate DURAN bottles, which were sealed immediately with Teflon-lined screw caps without head space to avoid $\mathrm{CO}_{2}$ exchange with the atmosphere. 


\section{4. Sampling and measurements}

2 Samples for total alkalinity $\left(A_{\mathrm{T}}\right)$ were $0.6 \mu \mathrm{m}$-filtered, stored in $150 \mathrm{~mL}$ borosilicate bottles at $3 \quad 3^{\circ} \mathrm{C}$ and analysed within a week. $A_{\mathrm{T}}$ was estimated from open-cell duplicate potentiometric 4 titration at $22 \pm 2^{\circ} \mathrm{C}$ calculated with modified Gran plots (Brewer et al., 1986) using a TitroLine alpha plus (Schott Instruments, Mainz, Germany). The calculated $A_{\mathrm{T}}$ values were corrected for offsets between $\mathrm{CRM}_{\text {measured }}$ and $\mathrm{CRM}_{\text {defined }}$ (on average $-13 \mu \mathrm{mol} \mathrm{kg}{ }^{-1}$; Certified Reference Materials Batch No. 54, Scripps Institution of Oceanography, USA). An internal North Sea seawater standard was additionally measured. The corrected $A_{\mathrm{T}}$ value was always $2445 \pm 5 \mu \mathrm{mol} \mathrm{kg}{ }^{-1}$ (repeatability; $\mathrm{n}=10$ ).

Dissolved inorganic carbon $\left(C_{\mathrm{T}}\right)$ samples were filtered through $0.2 \mu \mathrm{m}$ cellulose-acetate filters and stored in $5 \mathrm{~mL}$ gas-tight borosilicate bottles at $3{ }^{\circ} \mathrm{C}$. As samples were analysed within one week, potential decomposition of organic matter during this period is small and, in any case, would have increased $C_{\mathrm{T}}$ values rather than being suitable to explain the discrepancies described. $C_{\mathrm{T}}$ was measured colourimetrically in triplicate with a QuAAtro autoanalyzer (Seal, Mequon, USA). The analyser was calibrated with $\mathrm{NaHCO}_{3}$ solutions (with a salinity of 35, achieved by addition of $\mathrm{NaCl}$ ) with concentrations ranging from 1800 to $2300 \mu \mathrm{mol} C_{\mathrm{T}} \mathrm{kg}^{-1}$. CRMs were used for corrections of errors in instrument performance (baseline drift etc.). On average, the CRMs were measured with an offset of $3 \pm 5 \mu \mathrm{mol} \mathrm{kg}{ }^{-1}$ from the assigned value (reproducibility; $\mathrm{n}=20$ ). Shifts in $C_{\mathrm{T}}$ due to $\mathrm{CO}_{2}$ exchange were limited by opening the storage vials less than one minute prior to each measurement.

Seawater $\mathrm{pH}$ values were determined by two different approaches, potentiometrically as well as spectrophotometrically. In case of the NSW samples, $\mathrm{pH}_{\text {total }}$ was determined spectrophotometrically using $m$-cresol purple (Merck KGaG, Darmstadt, Germany; Clayton and Byrne, 1993, Dickson et al., 2007) using a temperature-controlled Cary 4000 UV-VISNIR spectrophotometer (Varian, Palo Alto, USA). The spectrophotometric $\mathrm{pH}_{\text {total }}$ was measured in technical duplicates at $25 \pm 0.1^{\circ} \mathrm{C}$, temperature-corrected and recalculated to $15.0^{\circ} \mathrm{C}$ using $\mathrm{CO}_{2}$ sys. The performance of the spectrophotometer used for the $\mathrm{pH}_{\text {total }}$ measurements (Cary 4000, Varian) was validated complying with the US Pharmacopeia requirements. Absorption measurements were corrected for background absorption (Dickson et al., 2007) and $\mathrm{pH}$ changes due to dye addition (calculated from the average effect of a second dye addition to every sample). Furthermore, the average values of CRM measurements (Tris-based $\mathrm{pH}$ reference materials) at the beginning and the end of one measuring run were used to correct the sample values. On average, the CRMs were measured with an offset of $-0.003 \pm 0.003$ from the assigned value (repeatability at $\mathrm{pH}=8.1 ; \mathrm{n}=7$ ). 
1 Carbonate chemistry calculations were based on total scale $\mathrm{pH}$ measurements. For the 2 potentiometric measurement (no replication), the glass reference electrode (IOline, Schott 3 Instruments) was calibrated using two buffers traceable back to NIST standards prior to every 4 set of measurements. The $\mathrm{pH}$ of NSW samples was thus measured on the NBS scale $\left(\mathrm{pH}_{\mathrm{NBS}}\right)$. 5 These potentiometric measurements were performed at $15 \pm 0.2^{\circ} \mathrm{C}$, temperature-corrected and 6 reported for $15.0^{\circ} \mathrm{C}$ using $\mathrm{CO}_{2}$ sys (Pierrot et al., 2006). The repeatability was $\pm 0.02 \mathrm{pH}$ units $7 \quad(\mathrm{n}=30)$. In the case of the ASW samples, seawater $\mathrm{pH}$ on the total scale $\left(\mathrm{pH}_{\text {total }}\right)$ was measured 8 potentiometrically. The measured $\mathrm{pH}_{\mathrm{NBS}}$ values were converted to the total scale using 9 respective CRMs after determining the offset of measured and assigned $\mathrm{pH}$ value (Tris-based $\mathrm{pH}$ reference material, Batch No. 2, Scripps Institution of Oceanography, USA).

$11 \mathrm{CO}_{2}$ concentrations were determined at $15 \pm 0.2^{\circ} \mathrm{C}$ in technical triplicates using a membrane-inlet mass spectrometer (MIMS; Tortell, 2005), which consists of a thermostated cuvette being connected to a sector field multi-collector MS (Isoprime; GV Instruments, 14 England). The MIMS was calibrated for $\mathrm{CO}_{2}$ by injections of known amounts of $\mathrm{NaHCO}_{3}$ into $8 \mathrm{ml}$ of $0.2 \mathrm{~N} \mathrm{HCl}$ (Schulz et al., 2006). The $\mathrm{CO}_{2}$ baseline was determined by addition of $20 \mu \mathrm{L} 10 \mathrm{~N} \mathrm{NaOH}$. $\mathrm{CO}_{2}$ concentrations were measured with a reproducibility of $\pm 0.13 \mu \mathrm{mol}$ $\mathrm{kg}^{-1}(\mathrm{n}=15)$.

\section{Calculations of carbonate chemistry}

20 Calculations were performed using the program $\mathrm{CO}_{2}$ sys (Pierrot et al., 2006) and verified with 21 the MATLAB files based on Zeebe and Wolf-Gladrow (2001). The dissociation constants of 22 carbonic acid of Mehrbach et al. (1973; refit by Dickson and Millero, 1989,) were used for calculations. Dissociation constants for $\mathrm{HSO}_{4}$ were taken from Dickson (1990). $\mathrm{CO}_{2}$ concentrations obtained with MIMS were converted to $f \mathrm{CO}_{2}$ by applying Henry's law (Weiss, 1974) and further converted to $p \mathrm{CO}_{2}$ using $\mathrm{CO}_{2}$ sys (Pierrot et al., 2006). 
1 Table 2. Measured carbonate chemistry parameters $\left(\mathrm{pH}, C_{\mathrm{T}}, A_{\mathrm{T}}\right.$ and $\left.\left[\mathrm{CO}_{2}\right]\right)$ and resulting $p \mathrm{CO}_{2}$ values calculated from different input parameters

2 using the constants of Mehrbach et al. (1973 refit by Dickson and Millero, 1987) at $15^{\circ} \mathrm{C}$. Errors denote standard deviation of technical replicates.

\begin{tabular}{|c|c|c|c|c|c|c|c|c|c|c|}
\hline & \multicolumn{5}{|c|}{ measured } & \multicolumn{4}{|c|}{ calculated } \\
\hline & & $\mathrm{pH}_{\mathrm{NBS}}$ & $\mathrm{pH}_{\text {total }}$ & $\begin{array}{c}C_{\mathrm{T}} \\
\left.(\mu \mathrm{mol} \mathrm{kg})^{-1}\right)\end{array}$ & $\begin{array}{c}A_{\mathrm{T}} \\
\left.(\mu \mathrm{mol} \mathrm{kg})^{-1}\right)\end{array}$ & $\begin{array}{c}\mathrm{CO}_{2} \\
(\mu \mathrm{mol} \mathrm{kg}-1) \\
\end{array}$ & $\begin{array}{c}p \mathrm{CO}_{2} \\
\text { (MIMS) } \\
\end{array}$ & $\begin{array}{c}p \mathrm{CO}_{2} \\
\left(A_{\mathrm{T}} ; C_{\mathrm{T}}\right) \\
\end{array}$ & $\begin{array}{c}p \mathrm{CO}_{2} \\
\left(A_{\mathrm{T}} ; \mathrm{pH}\right) \\
\end{array}$ & $\begin{array}{c}p \mathrm{CO}_{2} \\
\left(C_{\mathrm{T}} ; \mathrm{pH}\right) \\
\end{array}$ \\
\hline \multirow{6}{*}{ 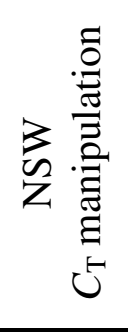 } & \multirow{3}{*}{ low $p \mathrm{CO}_{2}$} & 8.38 & $8.252 \pm 0.005$ & $1945 \pm 7$ & $2388 \pm 2$ & $8.34 \pm 0.14$ & 205 & 143 & 240 & 226 \\
\hline & & 8.39 & $8.319 \pm 0.001$ & $1946 \pm 7$ & $2385 \pm 3$ & $7.82 \pm 0.23$ & 203 & 145 & 198 & 191 \\
\hline & & 8.39 & $8.305 \pm 0.002$ & $1946 \pm 4$ & $2383 \pm 3$ & $7.73 \pm 0.23$ & 219 & 146 & 206 & 198 \\
\hline & \multirow{3}{*}{ high $p \mathrm{CO}_{2}$} & 7.91 & $7.735 \pm 0.001$ & $2254 \pm 1$ & $2396 \pm 1$ & $39.31 \pm 0.44$ & 1042 & 660 & 945 & 924 \\
\hline & & 7.88 & - & $2254 \pm 1$ & $2386 \pm 1$ & $38.10 \pm 0.02$ & 1000 & 701 & - & - \\
\hline & & 7.89 & $7.712 \pm 0.000$ & $2256 \pm 6$ & $2388 \pm 3$ & $42.59 \pm 0.02$ & 1117 & 702 & 998 & 976 \\
\hline \multirow{6}{*}{ 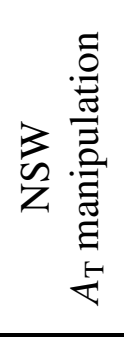 } & \multirow{3}{*}{ low $p \mathrm{CO}_{2}$} & 8.46 & $8.313 \pm 0.003$ & $2211 \pm 6$ & $2643 \pm 1$ & $9.06 \pm 0.07$ & 259 & 191 & 224 & 220 \\
\hline & & 8.48 & $8.318 \pm 0.012$ & $2217 \pm 6$ & $2642 \pm 0$ & $9.10 \pm 0.04$ & 268 & 196 & 221 & 218 \\
\hline & & 8.48 & $8.317 \pm 0.000$ & $2220 \pm 4$ & $2640 \pm 3$ & $8.60 \pm 0.08$ & 238 & 199 & 221 & 219 \\
\hline & \multirow{3}{*}{ high $p \mathrm{CO}_{2}$} & 7.72 & $7.616 \pm 0.004$ & $2186 \pm 2$ & $2276 \pm 1$ & $47.48 \pm 1.63$ & 1202 & 881 & 1205 & 1183 \\
\hline & & 7.81 & $7.610 \pm 0.004$ & $2180 \pm 4$ & $2278 \pm 3$ & $47.51 \pm 0.23$ & 1247 & 831 & 1224 & 1197 \\
\hline & & 7.79 & $7.617 \pm 0.013$ & $2186 \pm 1$ & $2276 \pm 1$ & $47.89 \pm 0.02$ & 1257 & 881 & 1202 & 1181 \\
\hline \multirow{9}{*}{ 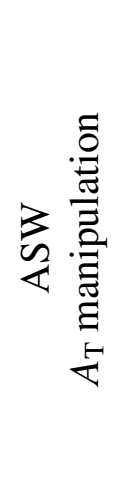 } & \multirow{3}{*}{ low $p \mathrm{CO}_{2}$} & - & 8.20 & $2192 \pm 1$ & $2612 \pm 0$ & - & - & 204 & 295 & 283 \\
\hline & & - & 8.20 & $2204 \pm 2$ & $2605 \pm 3$ & - & - & 220 & 301 & 291 \\
\hline & & - & 8.19 & $2206 \pm 0$ & $2597 \pm 2$ & - & - & 228 & 304 & 295 \\
\hline & \multirow{3}{*}{ intermed. $p \mathrm{CO}_{2}$} & - & 7.88 & $2184 \pm 1$ & $2390 \pm 1$ & - & - & 462 & 649 & 632 \\
\hline & & - & 7.88 & $2199 \pm 6$ & $2391 \pm 2$ & - & - & 498 & 649 & 636 \\
\hline & & - & 7.88 & $2199 \pm 1$ & $2389 \pm 1$ & - & - & 504 & 651 & 639 \\
\hline & \multirow{3}{*}{ high $p \mathrm{CO}_{2}$} & - & 7.60 & $2087 \pm 6$ & $2173 \pm 1$ & - & - & 875 & 1188 & 1166 \\
\hline & & - & 7.49 & $2119 \pm 4$ & $2172 \pm 2$ & - & - & 1127 & 1559 & 1530 \\
\hline & & - & 7.47 & $2122 \pm 6$ & $2172 \pm 3$ & - & - & 1159 & 1607 & 1577 \\
\hline
\end{tabular}




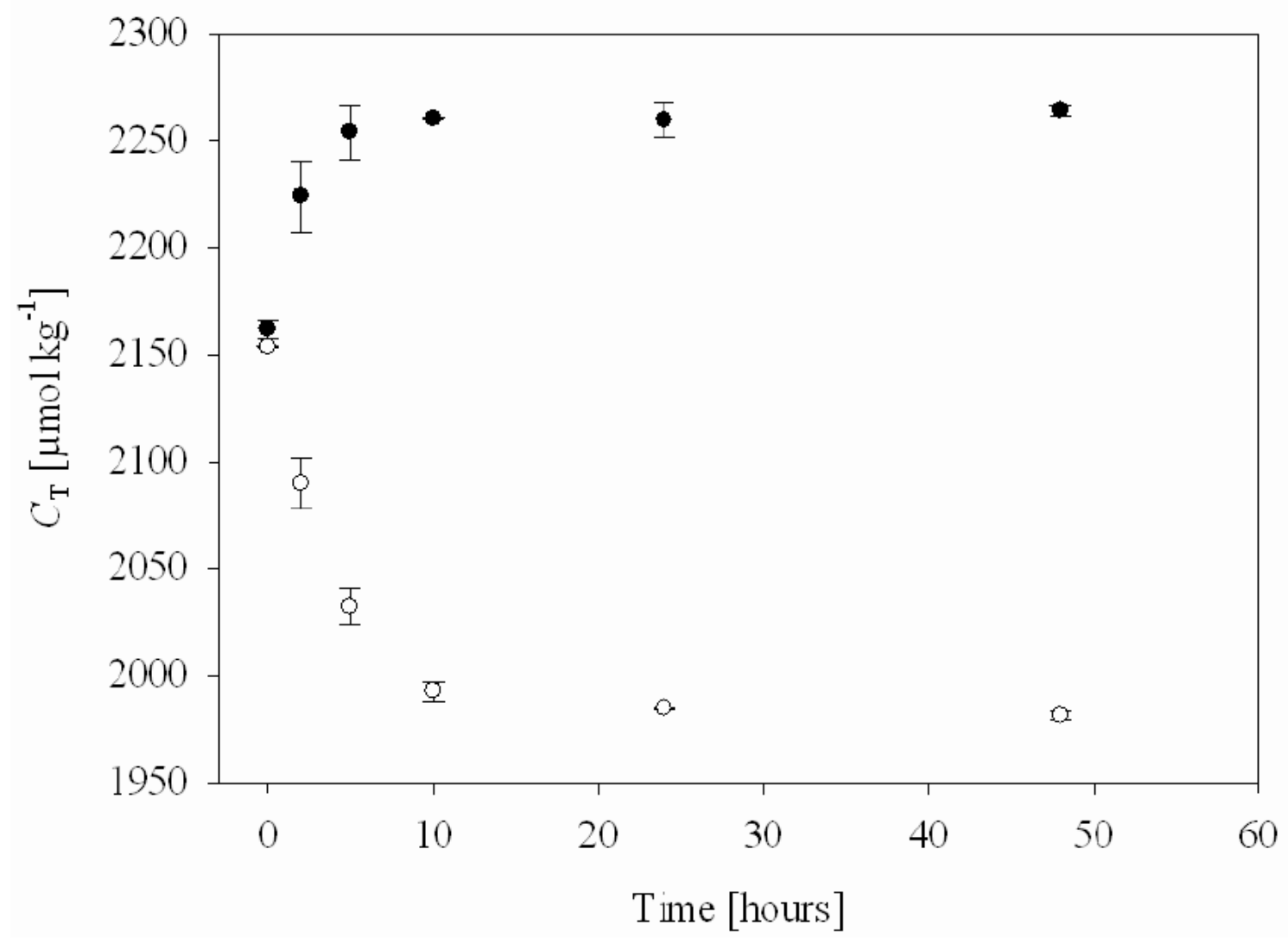

2 Figure 2. Equilibration kinetics in $C_{\mathrm{T}}$ manipulation experiments at $15^{\circ} \mathrm{C}$ represented by 3 changes in $C_{\mathrm{T}}$ at low (open circles) and high $p \mathrm{CO}_{2}$ (filled circles). Flow rates of equilibration 4 gasses were $130 \pm 10 \mathrm{~mL} \mathrm{~min}^{-1}$. 


\section{References}

Brewer, P. G., Bradshaw, A. L., and Williams, R. T.: Measurement of total carbon dioxide and alkalinity in the North Atlantic ocean in 1981, in: The Changing Carbon Cycle - A Global Analysis, Trabalka, J. R. and Reichle, D. E. (Eds.), Springer, Germany, 358-381, 1986.

Clayton, T. and Byrne, R. H.: Spectrophotometric seawater $\mathrm{pH}$ measurements: total hydrogen ion concentration scale calibration of $m$-cresol purple and at-sea results, Deep-Sea Res., 40, 2115-2129, 1993.

Dickson, A. G.: Standard potential of the reaction: $\operatorname{AgCl}(\mathrm{s})+1 / 2 \mathrm{H}_{2}(\mathrm{~g})=\mathrm{Ag}(\mathrm{s})+\mathrm{HCl}(\mathrm{aq})$, and the standard acidity constant of the ion $\mathrm{HSO}_{4}{ }^{-}$in synthetic seawater from 273.15 to 318.15 K, J. Chem. Thermodyn., 22, 113-127, 1990.

Dickson, A. G., Sabine, C. L., and Christian, J. R. (Eds.): Guide to best practices for ocean $\mathrm{CO}_{2}$ measurements, PICES Special Publication, 3, Sidney, Canada, 2007.

Guillard, R. R. L. and Ryther, J. H.: Studies of marine planktonic diatoms. I. Cyclothella nana Hustedt and Detonula confervacea Cleve, Can. J. Microbiol., 8, 229-239, 1962.

Grasshoff, K., Kremling, K., and Ehrhardt, M.: Methods of Seawater Analysis 3rd ed., WileyVCH, Weinheim, 1999.

Pierrot, D. E., Lewis, E., Wallace, D. W. R., 2006. MS Exel Program Developed for $\mathrm{CO}_{2}$ System Calculations, ORNL/CDIAC-105a, Carbon Dioxide Information Analysis Centre, Oak Ridge National Laboratory. US Department of Energy.

Tortell. P. D.: Dissolved gas measurements in oceanic waters made by membrane inlet mass spectrometry, Limnol. Oceanogr.: Methods, 3, 24-37, 2005.

Schulz, K. G., Riebesell, U., Rost, B., Thoms S., and Zeebe, R. E.: Determination of the rate constants for the carbon dioxide to bicarbonate inter-conversion in $\mathrm{pH}$-buffered seawater systems, Mar. Chem., 100, 53-65, 2006.

Weiss, R. F.: Carbon dioxide in water and seawater. The solubility of a non-ideal gas, Mar. Chem., 2, 203-215, 1974.

Zeebe, R. E. and Wolf-Gladrow, D. A.: $\mathrm{CO}_{2}$ in Seawater: Equilibrium, Kinetics, Isotopes, Elsevier Science, Amsterdam, The Netherlands, 2001. 